\title{
e-interview
}

\section{Kenneth S. Kendler}

Kenneth S. Kendler is Banks Distinguished Professor of Psychiatry, Professor of Human Genetics, and Director, Virginia Institute of Psychiatric and Behavioral Genetics, Virginia Commonwealth University. He attended Stanford University School of Medicine and did his residency in psychiatry at Yale University. His special interests include psychiatric genetics and the interface of psychiatry and philosophy.

\section{If you were not a psychiatrist, what} would you do?

I seriously considered going to graduate school in religious studies

What has been the greatest impact of your profession on you personally? My human experience has been much widened by my clinical experiences. I have had the privilege in both my clinical and research work to have been exposed to and been able to ponder many important questions about what makes humans as they are - to try to understand this 'paragon of animals'.

\section{What are your interests outside} of work?

When my kids were younger, playing and doing things with them was a high priority. I enjoy wilderness experiences and have gone to rather remote places in the world to hike. I exercise regularly, read poetry, play the piano and try to do things with my wife that we both enjoy.

Who was your most influential trainer, and why?

Lindon Eaves, my close colleague, teacher and friend, has certainly had the most profound influence on my thinking and career. His sparkling intellect shaped a variety of questions that I have asked over the years about how genes act and how they relate to environmental risks.

What research publication has had the greatest influence on your work? I was studying statistical genetics in Birmingham, UK in 1983. I went to the library and picked up the most recent issue of Nature. It contained Gusella's linkage study in

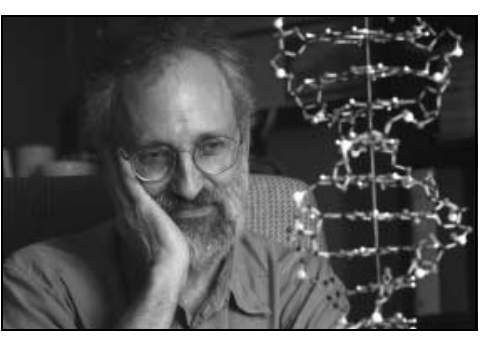

Huntington's chorea, the first successful linkage of a DNA marker to disease in humans (Gusella, J. F., Wexler, N.S., Conneally, P. M. et al (1983) A polymorphic DNA marker genetically linked to Huntington's disease. Nature, 306, 234238). I recall thinking to myself ' I wonder if it would ever be possible to apply this approach to psychiatric disorders.' Within 3 years, and with the help of several wonderful collaborators, we were funded to begin the collection of high-density schizophrenia pedigrees in Ireland

What part of your work gives you the most satisfaction?

I continue to experience much joy in the analysis of data and the writing up of results for publication. It can, on occasion, be very exciting. Giving a good talk where the audience is engaged and you have managed to convey information to them in a stimulating and interesting way can also be quite rewarding.

\section{What do you least enjoy?}

Worries about money/funding and dealing with staff who are not very good at what they do or, worse still, not very motivated.

\section{What conflict of interest do you} encounter most often?

There is a deep tension between the basic scholarly approach - to carefully and selfcritically seek to understand - that we theoretically value in academic psychiatry and the self-promotional, entrepreneurial style that is actually often more rewarded. We are at risk of confusing our goals (to produce knowledge) and the means to those goals (to obtain research funding). Sometimes the means appear to be more important than the goals.
Do you think psychiatry is brainless or mindless?

We are currently at some risk of becoming mindless. We have the challenge of integrating the advances that will be coming our way from genetics, imaging and molecular and systems neuroscience without losing our way as an integrative discipline. Although my 'day job' is studying genetic risk factors for psychiatric illness, it is clear that the environment is very important for most disorders and some of the critical aetiological factors in disease are tied up in deeply human processes such as meaning.

What are the main ethical problems that psychiatrists will face in the future?

I worry quite a bit about the influence of the pharmaceutical industry - how much they have been able to shape how we think about psychiatric disorders.

How would you improve clinical psychiatric training?

Our residents do not spend nearly enough time reading. They are often woefully ignorant about basic aspects of the history of psychiatry, of the classics of descriptive psychiatry. Only rarely in my experience do they have a basic knowledge of some of the broad conceptual and philosophical issues of relevance to our field.

What single area of psychiatric research should be given priority? It won't surprise you that I think that genetic studies, especially longitudinal investigations, that sample both DNA and obtain thoughtful measures of the environment, are likely to provide us with important insights. However, the level of conceptual and statistical sophistication in the way we approach these problems developing integrated 'multi-level' explanations of psychiatric illness - has a long way to go. Problems of multiple testing continue to dog our field and lead to overzealous claims about 'genes for' various disorders.

Dominic Fannon 